\title{
Tinjauan Pemodelan Sistem Dan Formulasi Economic Dispatch Untuk Sistem Tenaga Listrik Hibrida Berbasis Variable Renewable Energy Dengan PLTA Pumped Storage
}

\author{
Alam Tuara \\ Institut Teknologi PLN \\ alam1610016@itpln.ac.id
}

\begin{abstract}
In light of supporting the government program to reach a target of 23\% renewable energy in national energy mix by 2025 , one possible apporach is to couple utilization of local renewable energy sources with raising local maritime economic potentials that have not been optimized around thousands of Indonesian islands through out these years. This will also push towards the target of 9\% maritime economy contribution within national GDP of 2030, while at the same time, promotes sustainability from interdependency between renewable energy resources and the economic forces that utilize them. This research will take the first look at a simplified model of solar photovoltaic (PV)-based renewable energy integration into an existing sistem with diesel- and coal-based thermal units that have been built on those islands. Further within maximizing local renewable resources, a pumped hydro storage (PHS) utilizing sea water is picked for the choice of energy storage system, since its hydro generating unit should be capable of balancing out the variability of the PVsystem output. This research focuses on modelling a scheme of operation from integrating the VRE system, as well as consequences on the scheme of formulating the economic dispatch procedure for the thermal units as the result. The simplified model used in this research is intended to gain the very basic understanding on the fundamentals of operating scheme of the existing thermal units in accepting the integration of VRE system. Once it is well understood, this approach is potential for adaptation in thousands of islands in Indonesia, thus highly valueable to take the first look at it. The simulations show that the combination of PV system and the PHS are to be operated as must-run units. The consequences on the economic dispatch scheme is that they are to be treated as negative load, which in the end reduces the fossil-based fuel consumption in the power system.
\end{abstract}

Keywords: Large Scale PV, VRE Integration, Pumped Hydro Storage, Thermal Powerplant, Economic Dispatch

\begin{abstract}
ABSTRAK
Untuk mendukung program Pemerintah dalam pencapaian target 23\% EBT pada bauran energi nasional tahun 2025, salah satu pendekatan yang dapat digunakan adalah memasangkan pemanfaatan sumber energi terbarukan lokal untuk mendukung pengembangan perekonomian lokal di banyak pulau-pulau di Indonesia yang selama ini belum teroptimalkan. Hal ini juga akan mendorong target ekonomi maritim untuk dapat berkontribusi sebesar 9\% terhadap PDB nasional pada tahun 2030, dan sekaligus menciptakan sustainability dari saling ketergantungan antara sistem penyediaan energi dan kegiatan ekonomi yang memanfaatkannya. Penelitian ini akan melakukan tinjauan awal yang sederhana dengan memodelkan integrasi sistem PLTS berskala besar sebagai sumber energi terbarukan lokal ke dalam sistem tenaga listrik konvensional seperti PLTU dan PLTD yang banyak digunakan untuk melistriki pulau-pulau tersebut. Masih dalam rangka mengoptimalkan sumber energi terbarukan lokal, untuk mengimbangi sifat intermittent dari output sistem PLTS yang tergolong sebagai variable renewable energy
\end{abstract}




\section{JURNAL ILMIAH SUTET}

Vol. 10, No. 1, Juni 2020, P-ISSN 2356-1505, E-ISSN 2656-9175

https://doi.org/10.33322/sutet.v10i1.1167

(VRE), PLTA Pumped Storage (PLTA PS) yang memanfaatkan air laut akan dipilih sebagai sistem penyimpan energi yang PLTA-nya sekaligus mampu mengimbangi variasi output maupun fluktuasi yang terkadang ekstrim pada saat-saat tertentu. Penelitian ini akan berfokus pada pemodelan dari skema operasi serta perubahan dari skema formulasi economic dispatch untuk sistem pembangkit termal (PLTU dan PLTD) dengan adanya integrasi sistem PLTS berskala besar ke dalam jaringan. Pemodelan akan menggunakan sistem yang sederhana untuk memberikan pemahaman dasar terhadap fundamental skema operasi sistem konvensional yang menerima integrasi sistem VRE dalam rangka mengoptimalkan pemanfaatan sumber energi terbarukan lokal yang berpotensi untuk dikembangkan di ribuan pulau-pulau di Indonesia. Hasil simulasi menunjukkan energi terbarukan lokal dari kombinasi sistem PLTS dan PLTA PS yang dioperasikan sebagai must-run units, dan pada formulasi economic dispatch diperlakukan sebagai beban negatif, yang pada akhirnya bersifat mengurangi konsumsi bahan bakar fosil pada sistem tenaga listrik tersebut.

Kata kunci: PLTS Skala Besar, Integrasi VRE, PLTA Pumped Storage, Pembangkit Termal, Economic Dispatch 


\section{PENDAHULUAN}

Indonesia sebagai negara kepulauan memiliki banyak potensi ekonomi dari bidang kelautan dan perikanan. Banyak potensi perekonomian maritim yang belum teroptimalkan seperti perikanan tangkap maupun perikanan budidaya, serta potensi wisata bahari dan ekowisata lainnya, di daerah Terdepan, Terluar, dan Tertinggal (3T) di Indonesia. Hampir di seluruh daerah tersebut terdapat potensi energi terbarukan seperti Pembangkit Listrik Tenaga Surya (PLTS) dan/atau Pembangkit Listrik Tenaga Angin/Bayu (PLTB), yang dapat dimanfaatkan untuk mendukung kegiatan ekonomi lokal seperti tersebut diatas[1][3].

Pembangkit Listrik Tenaga Hibrida (PLTH) yang akan dirancang dengan memanfaatkan sumber energi lokal seperti PLTS/PLTB, terutama di daerah yang jauh dari jaringan PLN, dimana biaya pokok penyediaan (BPP) energi listrik cukup tinggi, dapat menjadi sumber energi yang kompetitif bila dibandingkan dengan pembangkit listrik konvensional berbasis energi fosil seperti Pembangkit Listrik Tenaga Diesel (PLTD) maupun Pembangkit Listrik Tenaga Uap (PLTU) berbahan bakar batubara[2][6].

Penelitian ini memodelkan sistem tenaga listrik hibrida untuk melistriki pulau berukuran kecil hingga sedang yang akan memerlukan energi untuk industri perikanan tangkap, perikanan budidaya, wisata bahari dan ekowisata lainnya termasuk untuk hotelhotel dan gedung-gedung komersial pendukung, di atas beban rutin rumah tangga penduduk dan infrastruktur dasar seperti sekolah, perkantoran, pertokoan, dan sebagainya. Model sistem tenaga listrik yang akan disimulasikan, akan mengikutkan pembangkit listrik termal konvensional berbasis fosil untuk menggambarkan kondisi awal yang masih berlangsung, dan bahwa hanya pembangkit tenaga listrik berbasis energi terbarukan lokal saja yang ditambahkan untuk mendukung pengembangan kapasitas ekonomi maritim yang baru di area kepulauan 3T seperti dimaksud diatas. Pemanfaatan sebanyak-banyaknya sumber energi lokal dimaksudkan untuk semakin mengefisienkan biaya pokok produksi listrik yang dihasilkan, dengan tujuan untuk meningkatkan daya saing produk industrinya[1][4].

Sistem energi terbarukan seperti PLTS/PLTB adalah Variable Renewable Energy (VRE) yang bersifat intermittent (outputnya berfluktuasi), yang biasanya memerlukan sistem penyimpan energi (energy storage) agar dapat dimanfaatkan secara optimal, dan dapat diintegrasikan dengan baik ke dalam sistem pembangkit listrik konvensional (sistem interkoneksi). Variasi output (intermittency) yang terjadi secara signifikan dalam waktu relatif singkat perlu diimbangi oleh energy storage seperti battery yang memiliki kecepatan respon yang tinggi, atau pembangkit reaksi cepat (quick response) seperti PLTA dan PLTD. Kemudian, variasi output (intermittency) yang terjadi dalam waktu yang relatif lebih lama, disebabkan oleh perubahan cuaca, hujan atau matahari yang tertutup awan (untuk PLTS), juga hilangnya hembusan angin (untuk PLTB), untuk sementara waktu. Intermittency yang seperti ini perlu diimbangi tidak hanya dengan reaksi cepat, namun juga memerlukan jumlah/volume energi pengimbang yang cukup. Dalam rangka meningkatkan kontribusi sumber energi terbarukan lokal, pada pemodelan sistem ini akan digunakan PLTA Pumped Storage (PLTA PS) menggunakan air laut untuk menyediakan volume energi pengimbang tersebut. PLTA PS dalam hal ini juga akan menjadi energy storage utama yang akan menyimpan energi dari PLTS yang akan digunakan untuk malam hari.

PLTA PS sudah lama dan banyak digunakan untuk mengoptimalkan capacity factor pembangkit termal dalam sistem interkoneksi, guna mengefisienkan konsumsi bahan bakar dan mengoptimalkan cost of energy produced (biaya bahan bakar per kWh energi listrik 
yang dihasilkan). Hal ini sama dengan mengoptimalkan BPP (Rp/kWh) energi listrik yang dihasilkan oleh sistem tersebut.

\section{METODE PENELITIAN}

Pada penelitian ini dilakukan pemodelan sistem tenaga listrik hibrida, lalu pengaturan operasional antara Variable Renewable Energy (VRE) yaitu PLTS Skala Besar dan PLTA Pumped Storage pada kurva beban. Kemudian juga dilakukan pembagian daya output dengan formulasi Economic Dispatch pada unit pembangkit termal yaitu PLTU dan PLTD. Penelitian ini akan menggunakan pola tipikal operasional pembangkit listrik selama seharian pada kurva beban (daily load curve) untuk mengolah data dan melakukan analisa.

Analisa yang akan dilakukan yaitu ketika proses pemompaan air laut oleh PLTA Pumped Storage menggunakan produksi daya PLTS pada saat periode penyinaran marahari dari pagi hingga sore selama 12 jam, kemudian skenario pembangkitan listrik oleh PLTA Pumped Storage pada malam hari yaitu saat matahari tidak bersinar selama 12 jam. Data operasional pembangkit yang digunakan yaitu load system demand 24 jam, lalu data output tiap-tiap pembangkit akan menggunakan data tipikal untuk memudahkan dalam melakukan analisa penelitian.

PLTS Skala Besar dibuat sebagai pembangkit utama pada sistem hibrida dan selama terdapat produksi daya PLTS maka harus selalu didahulukan untuk menyuplai daya penuh ke sistem (must run unit), sementara sisa daya PLTS akan dipakai PLTA PS untuk memompa air laut ke waduk atas. Karena pola operasi dari PLTA PS yang dapat juga dijadikan pengimbang intermittency, maka akan dipakai untuk mengimbangi output intermittent dari pembangkit VRE. Kemudian daya output pembangkit termal akan diatur serendah mungkin guna menghemat biaya operasional, pembagian daya output antara PLTU dan PLTD dalam menyuplai daya ke sistem akan dilakukan dengan formulasi Economic Dispatch menggunakan metode equal lambda.

\subsection{Perancangan Penelitian}

Perancangan penelitian berupa pemodelan sistem tenaga listrik dimana terdiri dari konfigurasi beberapa unit pembangkit sebagai objek, yang selanjutnya dilakukan pengaturan pembangkit dalam hal posisinya dalam kurva beban. Terdapat dua skenario yang dilakukan yaitu skenario siang hari dan skenario malam hari. Setelah dilakukan pemodelan pembangkit pada kurva beban, selanjutnya dilakukan analisis untuk mendapatkan hasil penelitian. 


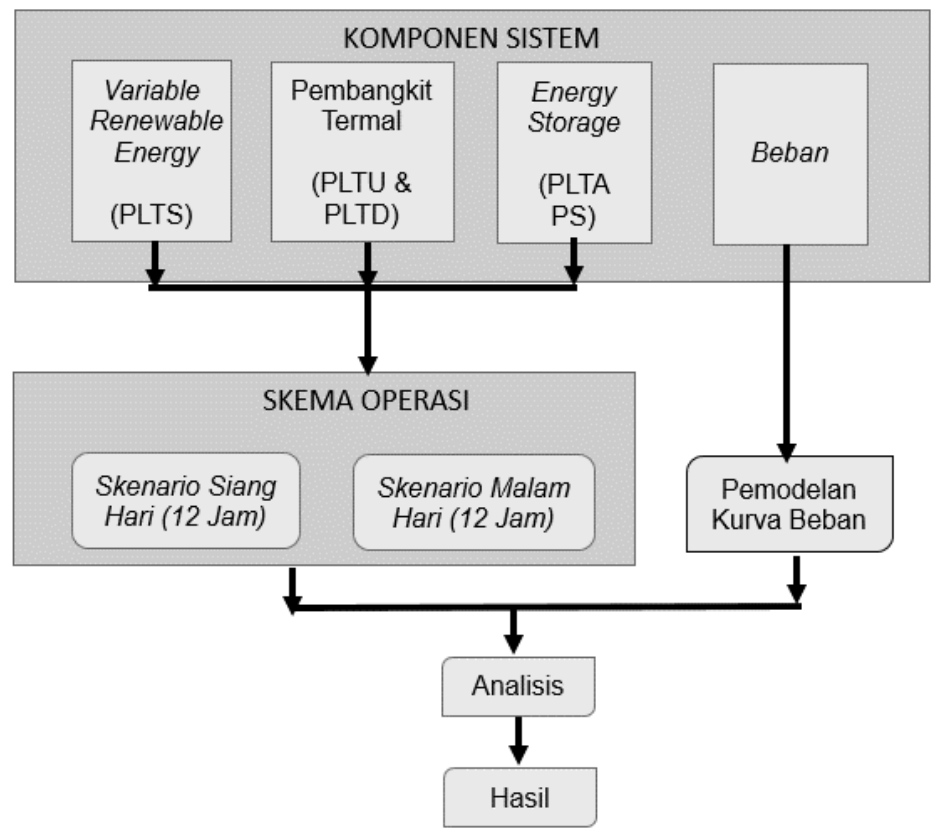

Gambar 1. Alur Penelitian

Pemodelan sistem PLTH untuk penerapan di pulau-pulau kecil hingga sedang dengan memanfaatkan potensi energi terbarukan lokal. Hal ini guna pengembangan potensi ekonomi maritim lokal seperti perikanan tangkap maupun budidaya beserta potensi ekowisata. Sebelumnya di pulau-pulau tersebut, diasumsikan sudah terpasang pembangkit termal konvensional seperti PLTU dan PLTD. Sistem yang telah ada akan dibantu dengan penyediaan energi listrik berbasis energi terbarukan lokal yaitu variable renewable energy (VRE) dan juga energy storage yang memanfaatkan air laut. Selanjutnya akan dilakukan analisis dan pemodelan kurva beban terhadap unit-unit pembangkit. Dimana objeknya yaitu pembangkit termal, VRE, energy storage, serta kurva beban, akan dilakukan skema pola operasi dengan dua skenario yaitu pada malam hari dan siang hari.

\subsection{Pendekatan PLTS dan PLTA PS Sebagai Beban Negatif}

PLTS merupakan pembangkit listrik yang sumber energinya dari sinar matahari, sehingga pembangkit jenis ini hanya bisa menghasilkan listrik dari pagi hari sejak pukul 06:00 hingga sore pukul 17:00 (12 jam). Daya output PLTS dapat kita prediksi seperti memprediksi perkiraan beban sistem dengan memperhatikan data ramalan cuaca. PLTS sebagai pembangkit renewable energy tidak membutuhkan bahan bakar, PLTS dikategorikan must run unit sehingga semua produksi daya harus langsung dipakai untuk menyuplai beban [21]. Sehingga perhitungan Equality Constraint dapat dihitung menggunakan persamaan sebagai berikut :

$\sum_{t=06.00}^{17.00} P D_{t}=\sum_{t=06.00}^{17.00}\left(\operatorname{PLoad}_{t}-\sum_{q=1}^{N} P p v_{q, t}\right) M W$

Dimana :

PDt = Jumlah permintaan beban di sistem pada saat waktu t (MW)

PLoadt $=$ Total beban sistem saat waktu $\mathrm{t}(\mathrm{MW})$ 
Ppvq,t = Daya output PLTS ke-q saat waktu t (MW)

PLTA PS merupakan pembangkit yang tidak membutuhkan bahan bakar, namun memanfaatkan air yang ditampung pada reservoir, sehingga PLTA PS dijadwalkan untuk membangkitkan listrik pada saat sore hingga pagi hari. Besarnya daya listrik yang dibangkitkan bergantung pada tingkat jumlah air yang ditampung. Periode penyaluran air dari reservoir atas ke bawah dari pukul 18:00 sore hingga 05:00 pagi (12 jam). Sehingga perhitungan Equality Constraint dapat dihitung menggunakan persamaan sebagai berikut :

$\sum_{t=18.00}^{05.00} P D_{t}=\sum_{t=18.00}^{05.00}\left(\right.$ PLoad $\left._{t}-\sum_{q=1}^{K} P p s_{q, t}\right) M W$

Dimana :

PDt = Jumlah permintaan beban di sistem pada saat waktu t (MW)

PLoadt $=$ Total beban sistem saat waktu $\mathrm{t}(\mathrm{MW})$

Ppsq, $\mathrm{t}$ = Daya output PLTA PS ke-q saat waktu $\mathrm{t}(\mathrm{MW})$

\section{HASIL DAN PEMBAHASAN}

\subsection{Pemodelan Pembangkit Listrik Pada Sistem Tenaga Listrik Hibrida}

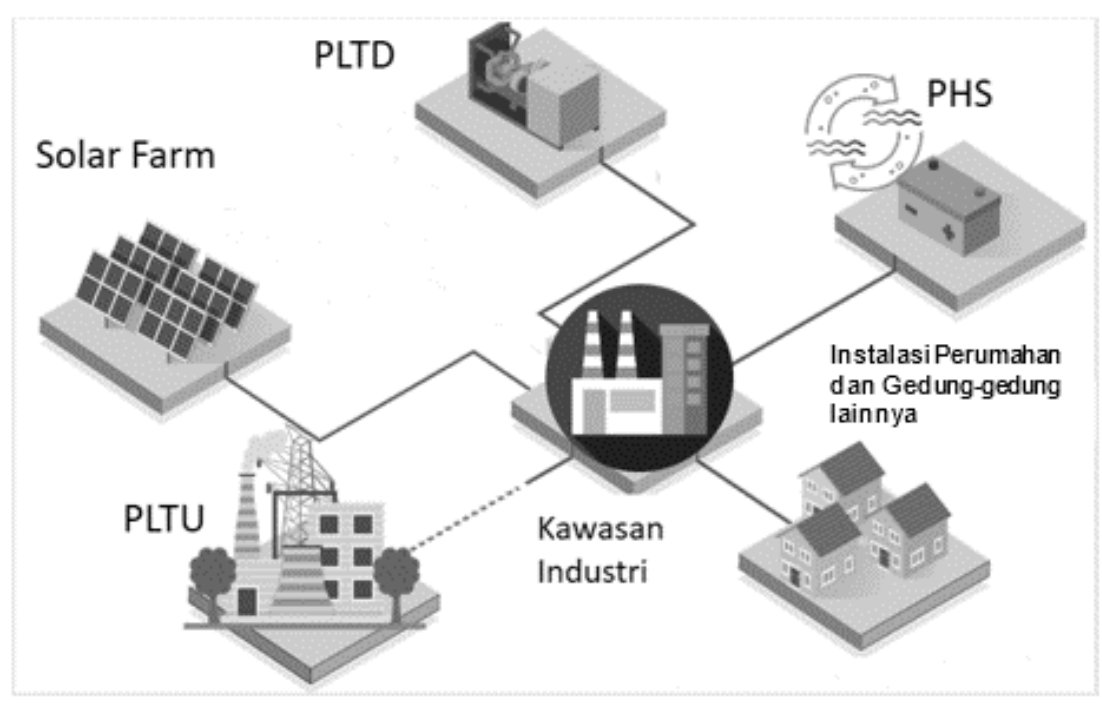

Gambar 2. Model Sistem

Sistem tenaga listrik hibrida dirancang dengan konfigurasi sistem pembangkit yaitu tersedia beberapa unit pembangkit antara lain PLTU, PLTD, PLTS dan PLTA PS dengan kapasitas pembangkit yang berbeda. Pemodelan kurva beban seperti Gambar 2 akan disuplai oleh PLTS Skala Besar berkapasitas 20 MWp dan PLTA PS dengan kapasitas 100 MWh, dimana PLTS dan PLTA PS bekerja secara bergantian (skenario siang hari dan malam hari) untuk menyuplai beban. Lalu kemudian sisa beban akan disuplai oleh pembangkit konvensional yaitu PLTU berkapasitas 15 MW dan PLTD berkapasitas 10 MW sebagai pembangkit penyeimbang yang mengikuti pergerakan beban. 


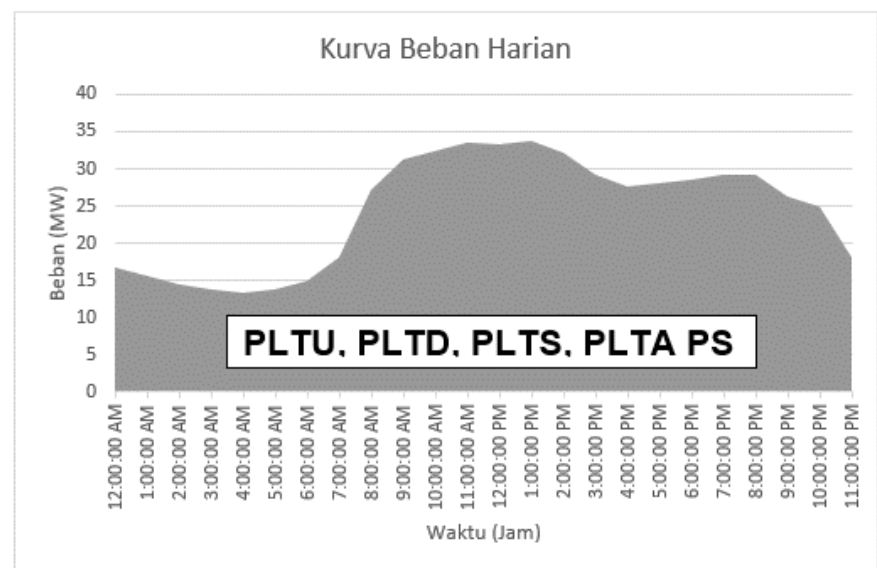

Gambar 3. Kurva Beban Harian

PLTS menyuplai listrik ke sistem pada siang hari sementara PLTA PS menyuplai listrik ke sistem pada malam hari. Pada siang hari, sebagian daya produksi PLTS digunakan untuk langsung memenuhi beban dan sebagian lagi digunakan untuk memompa air laut ke reservoir atas pada PLTA PS. PLTA PS berguna sebagai penyimpan energi (energy storage) yang digunakan untuk membangkitkan listrik pada malam hari, selain itu PLTA PS juga berfungsi untuk mengimbangi variabilitas daya output PLTS pada sistem.

\subsection{Penentuan Daya Output PLTS Skala Besar (Skenario Siang Hari)}

Pada skenario siang hari, PLTS $20 \mathrm{MWp}$ beroperasi selama 12 jam dari jam 6 pagi hingga jam 6 sore. Seperti terlihat pada Tabel 1, daya output PLTS terbagi menjadi 2 yaitu $X$ sebesar $60 \%$ untuk memenuhi beban siang, sementara sisanya yaitu $Y$ sebesar $40 \%$ untuk dipakai oleh PLTA PS. Pada saat siang hari PLTA PS akan beroperasi memompa air laut menggunakan daya PLTS, untuk nantinya dipakai menyuplai beban malam.

Tabel 1. Daya Output PLTS Skala Besar

\begin{tabular}{|c|c|c|c|c|}
\hline \multirow[b]{3}{*}{ No } & \multirow[b]{3}{*}{ Waktu } & \multicolumn{3}{|c|}{ Daya Output PLTS (MW) } \\
\hline & & \multirow[b]{2}{*}{$\begin{array}{c}\text { Total } \\
\text { PLTS } \\
(\mathrm{X}+\mathrm{Y})\end{array}$} & $60 \%$ & $40 \%$ \\
\hline & & & $\begin{array}{c}\text { X } \\
\text { (Suplai } \\
\text { Beban) }\end{array}$ & $\begin{array}{c}Y \\
\text { (Pompa } \\
\text { Air) }\end{array}$ \\
\hline 1 & 6:00:00 & 4.4 & 2.64 & 1.76 \\
\hline 2 & 7:00:00 & 6 & 3.6 & 2.40 \\
\hline 3 & 8:00:00 & 10 & 6 & 4.00 \\
\hline 4 & 9:00:00 & 13 & 7.8 & 5.20 \\
\hline 5 & $10: 00: 00$ & 14 & 8.4 & 5.60 \\
\hline 6 & $11: 00: 00$ & 17 & 10.2 & 6.80 \\
\hline 7 & $12: 00: 00$ & 19 & 11.4 & 7.60 \\
\hline 8 & 13:00:00 & 16.2 & 9.72 & 6.48 \\
\hline 9 & $14: 00: 00$ & 13 & 7.8 & 5.20 \\
\hline 10 & $15: 00: 00$ & 11 & 6.6 & 4.40 \\
\hline 11 & $16: 00: 00$ & 6 & 3.6 & 2.40 \\
\hline 12 & $17: 00: 00$ & 3.6 & 2.16 & 1.44 \\
\hline
\end{tabular}




\subsection{Penentuan Daya Output PLTA Pumped Storage (Skenario Malam Hari)}

Sebelum PLTA PS mulai beroperasi untuk pertama kalinya, PLTA PS akan memompa air (mengisi waduk atas) untuk kapasitas sekitar 2 hari autonomy days, sehingga total kapasitas PLTA PS adalah 100 MWh. Pada skenario malam hari saat PLTS telah berhenti beroperasi, dengan asumsi efisiensi $75 \%$ (Ariyadi, 2018) PLTA PS akan menyuplai daya $(75 \% \times$ Y) untuk memenuhi beban malam selama 12 jam sejak jam 6 sore hingga jam 6 pagi.

Tabel 2. Daya PLTA Pumped Storage

\begin{tabular}{|c|c|c|}
\hline $\begin{array}{l}\text { Waktu } \\
\text { (Jam) }\end{array}$ & $\begin{array}{c}(\mathrm{Y}) \\
\text { Kapasitas } \\
\text { PLTAPS } \\
\text { (MWh) }\end{array}$ & $\begin{array}{c}\text { Mode } \\
\text { Operasi }\end{array}$ \\
\hline $6: 00: 00$ & 1.76 & \multirow{12}{*}{$\begin{array}{c}\text { Pumping } \\
\text { Mode } \\
\text { (53.28 } \\
\text { MWh) }\end{array}$} \\
\hline 7:00:00 & 2.40 & \\
\hline $8: 00: 00$ & 4.00 & \\
\hline 9:00:00 & 5.20 & \\
\hline 10:00:00 & 5.60 & \\
\hline 11:00:00 & 6.80 & \\
\hline $12: 00: 00$ & 7.60 & \\
\hline $13: 00: 00$ & 6.48 & \\
\hline 14:00:00 & 5.20 & \\
\hline 15:00:00 & 4.40 & \\
\hline $16: 00: 00$ & 2.40 & \\
\hline 17:00:00 & 1.44 & \\
\hline
\end{tabular}

\begin{tabular}{|c|c|c|}
\hline $\begin{array}{l}\text { Waktu } \\
\text { (Jam) }\end{array}$ & $\begin{array}{c}(75 \% \text { Y) } \\
\text { Kapasitas } \\
\text { PLTA PS } \\
(\mathrm{MWh})\end{array}$ & $\begin{array}{c}\text { Mode } \\
\text { Operasi }\end{array}$ \\
\hline $18: 00: 00$ & 3.33 & \multirow{12}{*}{$\begin{array}{c}\text { Generating } \\
\text { Mode } \\
(39.96 \\
\text { MWh / } 12 \\
\text { Jam) }\end{array}$} \\
\hline $19: 00: 00$ & 3.33 & \\
\hline $20: 00: 00$ & 3.33 & \\
\hline $21: 00: 00$ & 3.33 & \\
\hline 22:00:00 & 3.33 & \\
\hline $23: 00: 00$ & 3.33 & \\
\hline 0:00:00 & 3.33 & \\
\hline 1:00:00 & 3.33 & \\
\hline $2: 00: 00$ & 3.33 & \\
\hline $3: 00: 00$ & 3.33 & \\
\hline 4:00:00 & 3.33 & \\
\hline $5: 00: 00$ & 3.33 & \\
\hline
\end{tabular}

Kapasitas daya autonomy days PLTA PS tersedia untuk penggunaan antara 2-3 hari yang telah diisi terlebih dahulu saat awal PLTA PS mulai dioperasikan.

- Bila terjadi kekurangan output PLTS (PVoutput $<Y$ ), sehingga suplai daya PLTA PS berkurang, maka untuk mengisi kekurangan kapasitas beban malamnya, akan diambilkan dari kapasitas reserve autonomy days, kemudian kapasitas autonomy days harus diganti dengan kapasitas dari yang berikut sesuai urutan prioritas:

- Kalo ada hujan maka diasumsikan autonomy days sudah akan terkompensasi

- Diasumsikan bahwa pengoptimalan capacity factor PLTU di malam hari akan melebihi target recovery kapasitas autonomy days

- Dalam situasi kekurangan yang ekstrim, PLTU selanjutnya dapat digunakan untuk memenuhi kekurangan autonomy days

\subsection{Pengaturan Pembagian Daya Economic Dispatch PLTU dan PLTD}

Proses Economic Dispatch dilakukan pada pembangkit termal yaitu PLTU dan PLTD untuk mengetahui komposisi optimal dan ekonomis daya yang harus disuplai untuk memenuhi sisa beban sistem. Pada saat pemodelan operasional sistem, telah didahulukan pembangkit konvensional yaitu PLTS dan PLTA PS, lalu akan diikuti oleh PLTU dan PLTD dengan skema pembagian daya equal incremental cost. 
Tersedia dua unit pembangkit termal dengan karakteristik biaya (cost characteristic): $C_{1}=0.75 P_{1}^{2}+170 P_{1}+2000 R p / M W h$ $C_{2}=1.3 P_{2}^{2}+145 P_{2}+2500 R p / M W h$

Cost function:

\begin{tabular}{|c|c|c|c|}
\hline & $a$ & $b$ & $c$ \\
\hline $\mathrm{C} 1=$ & 0.75 & 170 & 2000 \\
\hline $\mathrm{C} 2=$ & 1.3 & 145 & 2500 \\
\hline
\end{tabular}

$C_{i}=\alpha_{i} P_{i}^{2}+\beta_{i} P_{i}+\gamma_{i}$
Incremental Cost:

\begin{tabular}{|l|c|c|}
\hline & $a$ & $b$ \\
\hline $\mathrm{C} 1=$ & 1.5 & 170 \\
\hline $\mathrm{C} 2=$ & 2.6 & 145 \\
\hline
\end{tabular}

$I C_{i}=\frac{d C_{i}}{d P_{i}}=2 \alpha_{i} P_{i}+\beta_{i}=\lambda$

Berdasarkan karakteristik biaya (cost characteristic) tersebut maka dapat ditentukan incremental cost pembangkit. Setelah diketahui incremental cost pembangkit, selanjutnya penentuan nilai lambda $(\lambda)$. Nilai lambda tersebut akan dipakai untuk penentuan daya output pembangkit termal P1 dan P2.

Prosedur pembagian daya antara PLTU dan PLTD akan dilakukan dengan prinsip equal incremental cost atau equal lambda, sehingga didapatkan hasil daya output PLTU dan PLTD seperti terlihat pada Tabel 3. Perhitungan Economic Dispatch dengan prinsip equal incremental cost dilakukan dalam rentang perjam selama seharian penuh (24 jam), terdapat 24 perhitungan untuk 24 titik jam. Perhitungan dilakukan dengan bantuan software Microsoft Excel.

Tabel 3. Pembagian Daya Output PLTU dan PLTD

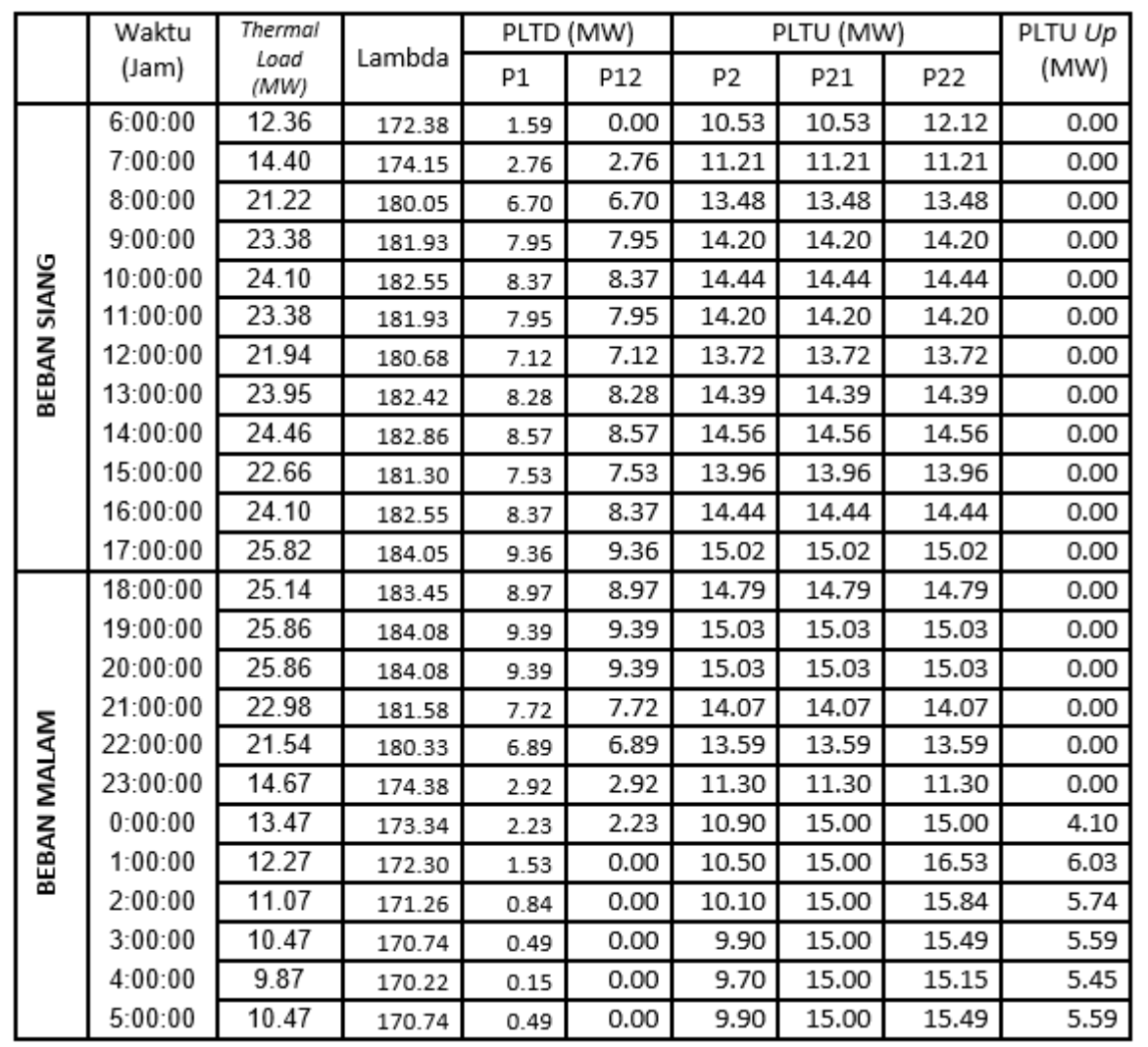

Keterangan Tabel IV:

$\mathrm{PLTD} 10 \mathrm{MW} \rightarrow \mathrm{Pmin}=2 \mathrm{MW} ; \mathrm{Pmax}=10 \mathrm{MW}$ 
PLTU $25 \mathrm{MW} \rightarrow \mathrm{Pmin}=10 \mathrm{MW} ; \mathrm{P}_{\text {efficiency }}=15 \mathrm{MW} ; \mathrm{Pmax}=25 \mathrm{MW}$

Daya Output PLTD :

1) Nilai P1 merupakan daya output PLTD, hasil pembagian daya menggunakan metode equal incremental cost (equal lambda).

2) Nilai P12 adalah jika P1 kurang dari 2 MW (Pmin PLTD), maka PLTD diset jadi 0 (dimatikan). Jika P1 lebih atau sama dengan dari 2 MW (Pmin PLTD), maka nilai tetap.

Daya Output PLTU :

1) Nilai P2 merupakan daya output PLTU, hasil pembagian daya menggunakan metode equal incremental cost (equal lambda).

2) Nilai P21 adalah jika PLTU (P2) beroperasi mendekati nilai Pmin maka akan dinaikkan ke titik efisiensi PLTU yaitu $15 \mathrm{MW}$

3) Nilai P22 adalah daya PLTU setelah P21 ditambah beban dari PLTD (P1) akibat PLTD dimatikan

4) Kolom nilai PLTU Out merupakan sisa daya PLTU setelah suplai beban, ketika efisiensi PLTU dinaikkan ke titik optimalnya saat waktu LWBP, daya tersebut dipakai PLTA PS untuk memompa air

\subsection{Perhitungan Skema Operasi Pembangkit Memenuhi Kurva Beban}

Hasil konfigurasi daya output pembangkit dalam sistem guna memenuhi kurva beban, baik beban siang hari maupun beban malam hari seperti terlihat pada Tabel 4 .

Tabel 4. Konfigurasi Sistem Disuplai Oleh Semua Pembangkit

\begin{tabular}{|c|c|c|c|c|c|c|}
\hline \multirow{2}{*}{ No } & \multirow{2}{*}{$\begin{array}{c}\text { Waktu } \\
(\text { Jam) }\end{array}$} & Beban (MW) & \multicolumn{4}{|c|}{ Daya Pembangkit (MW) } \\
\cline { 6 - 7 } & & $\begin{array}{c}\text { Beban } \\
\text { Siang }\end{array}$ & \multirow{2}{*}{ PLTS } & $\begin{array}{c}\text { PLTA } \\
\text { PS }\end{array}$ & \multicolumn{2}{|c|}{ Termal Unit } \\
\cline { 6 - 7 } 1 & $6: 00: 00$ & 15.00 & 2.64 & 0 & 10.53 & 1.59 \\
\hline 2 & $7: 00: 00$ & 18.00 & 3.6 & 0 & 11.21 & 2.76 \\
\hline 3 & $8: 00: 00$ & 27.22 & 6 & 0 & 13.48 & 6.70 \\
\hline 4 & $9: 00: 00$ & 31.18 & 7.8 & 0 & 14.20 & 7.95 \\
\hline 5 & $10: 00: 00$ & 32.50 & 8.4 & 0 & 14.44 & 8.37 \\
\hline 6 & $11: 00: 00$ & 33.58 & 10.2 & 0 & 14.20 & 7.95 \\
\hline 7 & $12: 00: 00$ & 33.34 & 11.4 & 0 & 13.72 & 7.12 \\
\hline 8 & $13: 00: 00$ & 33.67 & 9.72 & 0 & 14.39 & 8.28 \\
\hline 9 & $14: 00: 00$ & 32.26 & 7.8 & 0 & 14.56 & 8.57 \\
\hline 10 & $15: 00: 00$ & 29.26 & 6.6 & 0 & 13.96 & 7.53 \\
\hline 11 & $16: 00: 00$ & 27.70 & 3.6 & 0 & 14.44 & 8.37 \\
\hline 12 & $17: 00: 00$ & 27.98 & 2.16 & 0 & 15.02 & 9.36 \\
\hline No & Waktu & Beban & PLTS & PLTA & Termal Unit \\
\cline { 6 - 7 } & $($ Jam) & Malam & & PS & PLTU & PLTD \\
\hline 13 & $18: 00: 00$ & 28.47 & 0 & 3.33 & 14.79 & 8.97 \\
\hline 14 & $19: 00: 00$ & 29.19 & 0 & 3.33 & 15.03 & 9.39 \\
\hline 15 & $20: 00: 00$ & 29.19 & 0 & 3.33 & 15.03 & 9.39 \\
\hline 16 & $21: 00: 00$ & 26.31 & 0 & 3.33 & 14.07 & 7.72 \\
\hline 17 & $22: 00: 00$ & 24.87 & 0 & 3.33 & 13.59 & 6.89 \\
\hline 18 & $23: 00: 00$ & 18.00 & 0 & 3.33 & 11.30 & 2.92 \\
\hline 19 & $0: 00: 00$ & 16.80 & 0 & 3.33 & 10.90 & 2.23 \\
\hline 20 & $1: 00: 00$ & 15.60 & 0 & 3.33 & 10.50 & 1.53 \\
\hline 21 & $2: 00: 00$ & 14.40 & 0 & 3.33 & 10.10 & 0.84 \\
\hline 22 & $3: 00: 00$ & 13.80 & 0 & 3.33 & 9.90 & 0.49 \\
\hline 23 & $4: 00: 00$ & 13.20 & 0 & 3.33 & 9.70 & 0.15 \\
\hline 24 & $5: 00: 00$ & 13.80 & 0 & 3.33 & 9.90 & 0.49 \\
\hline & & & & & & \\
\hline
\end{tabular}


Pola Operasi Beban Siang :

1) Beban siang akan dilayani oleh X kapasitas PLTS

2) Untuk setiap jam siang, sisa beban setelah disuplai PLTS, akan dilayani pembangkit termal (PLTU dan PLTD) melalui prinsip perhitungan "equal lambda"

3) Pompa pengisi air untuk malam hari akan dilayani oleh Y kapasitas PLTS

Pola Operasi Beban malam :

1) Beban malam akan dilayani oleh PLTA PS malam

i. Kapasitas air waduk untuk malam hari tersebut dibagi rata dengan jumlah jam operasi malam (12 jam)

ii. Lalu beban setiap jam dikurangi dengan bangkitan PLTA di setiap jam

2) Untuk setiap jam malam, sisa beban setelah disuplai PLTA PS, akan dilayani (PLTU dan PLTD) melalui prinsip perhitungan "equal lambda"

3) Bila kapasitas air sedang kurang, sehingga beban malam menjadi lebih kecil, kapasitas air untuk autonomy days tetap tidak boleh digunakan untuk melayani beban malam, dengan demikian unit termal (PLTU dan PLTD) akan melayani beban lebih banyak

4) Bila kapasitas air sedang berlebih, maka beban malam akan menjadi lebih besar, dengan demikian unit termal (PLTU dan PLTD) akan melayani beban lebih sedikit

Berdasarkan data-data hasil simulasi kemudian dibuatlah kurva beban seperti pada Gambar 4. Terlihat kurva beban tersebut telah diatur pembagian bebannya berdasarkan pemodelan pembangkit PLTS dan PLTA PS, kemudian juga skema pembagian daya Economic Dispatch pada PLTU dan PLTD dengan metode equal lambda. Terdapat kondisi dimana pada luar waktu beban puncak (LWBP) permintaan beban rendah yang mengakibatkan daya keluaran PLTU berada dibawah batas efisiensinya, sehingga daya PLTU dinaikkan ke level efisiensinya dengan menggunakan daya tersebut untuk memompa air.

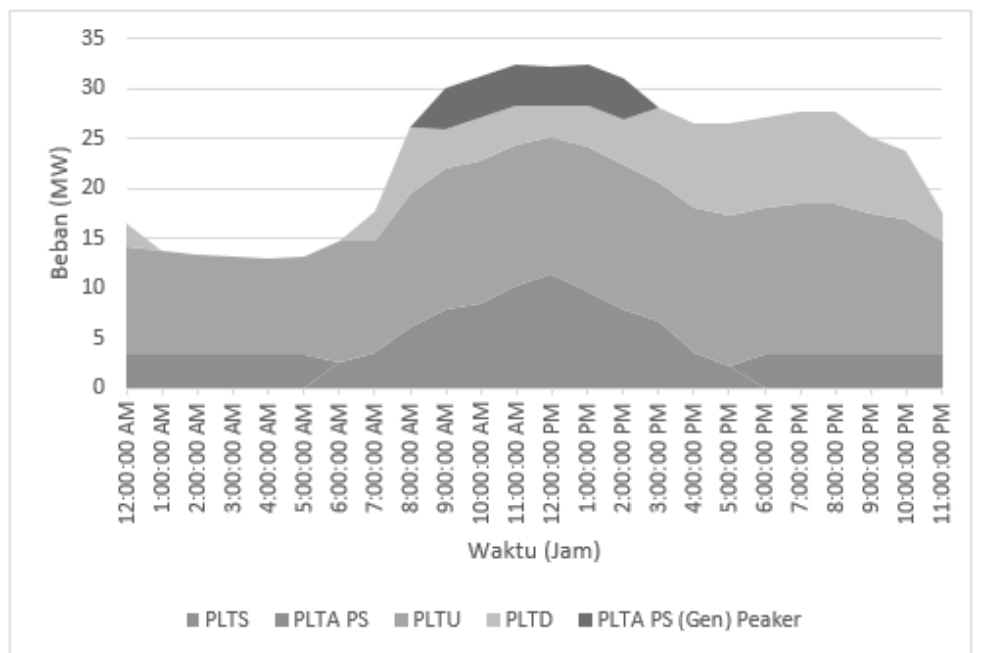

Gambar 4. Konfigurasi Pembangkit dalam Memenuhi Kurva Beban

PLTU dengan kapasitas 25 MW diatur untuk bekerja pada titik optimal (capacity factor) yaitu $60 \%$ dari total kapasitas. Capacity factor merupakan perbandingan jumlah 
produksi listrik dalam periode tertentu terhadap kemampuan produksi sesuai daya mampu pembangkit. Titik optimal diatur pada $15 \mathrm{MW}$, sehingga apabila permintaan beban dibawah 15 MW dan PLTU bekerja dibawah titik optimalnya maka konsumsi bahan bakar akar boros dan juga mesin bekerja tidak efisian, sehingga daya output PLTU akan dinaikkan menjadi $15 \mathrm{MW}$ dengan menyuplai listrik ke PLTA PS untuk memompa air. Kemudian daya tersebut akan dipakai pada saat kondisi waktu beban puncak (WBP) seperti terlihat pada Gambar 4 (arsiran warna biru tua), beban puncak disuplai oleh PLTA PS Peaker.

Demikian hasil dari pemodelan sistem dan simulasi serta penerapan formulasi Economic Dispatch untuk sistem tenaga listrik hibrida berbasis Variable Renewable Energy dengan PLTA Pumped Storage. Sistem seperti yang telah dirancang dapat diterapkan di Indonesia dengan memanfaatkan sumber energi terbarukan lokal, karena banyak pulaupulau kecil dengan sumber air laut yang banyak dan juga sinar matahari yang berlimpah. Pemodelan sistem pada penelitian ini dapat juga diterapkan pada daerah terisolasi yang tidak terhubung pada sistem kelistrikan interkoneksi.

\section{KESIMPULAN DAN SARAN}

\subsection{Kesimpulan}

1. Penelitian ini telah melakukan pemodelan pemanfaatan sumber energi terbarukan lokal seperti sistem PLTS beserta PLTA PS, untuk mendukung sistem pembangkit termal konvensional yang diasumsikan sudah eksisting terlebih dahulu disebuah pulau.

2. Penelitian ini telah melakukan simulasi operasi sistem PLTH dengan mengkombinasikan PLTS beserta PLTA PS untuk mendukung sistem eksisting yang terdiri dari PLTU dan PLTD.

3. Penelitian ini telah melakukan kajian formulasi Economic Dispatch bagi sistem pembangkit termal PLTU dan PLTD yang menerima masukan VRE dari sistem PLTS dengan dukungan energy storage berupa PLTA PS yang memanfaatkan air laut.

\subsection{Saran}

1. Kelebihan dari hasil pemodelan sistem pada penelitian ini yaitu dapat dijadikan sebagai contoh skema operasi sistem PLTH yang mengkombinasikan unit-unit pembangkit termal konvensional, dengan pembangkit VRE yang bersifat intermittent, serta energy storage menggunakan PLTA PS yang memanfaatkan air laut, untuk pulau-pulau berukuran kecil hingga sedang, guna mendukung kegiatan ekonomi lokal dengan memanfaatkan potensi energi terbarukan lokal.

2. Kekurangan dari hasil pemodelan sistem pada penelitian ini yaitu masih minimnya sumber data pendukung dalam proses pembuatan skema operasi sistem. Kemudian juga, skema yang diusulkan masih perlu dikaji lebih jauh lagi baik dari segi kelayakan finansial ataupun investasi pembangunannya. 


\section{DAFTAR PUSTAKA}

[1] A.Daryanto Ariyadi. (2018). Tekno-ekonomi PLTA pumped storage. Bandung: Institut Teknologi Bandung (ITB).

[2] Aditya, Nanda. (2016). Studi fluktuasi daya output sistem PLTS skala besar untuk menentukan kapasitas cadangan putar di unit pembangkitan (UP) cirata. Jakarta: Sekolah Tinggi Teknik - PLN.

[3] Botterud, A., Levin, T., Koritarov, V. (2014). Pumped storage hydropower: benefits for grid reliability and integration of variable renewable energy. US: Argonne National Laboratory.

[4] Destarella, Essy. (2019). Tinjauan fungsi dan pemanfaatan PLTA pumped storage dalam sistem tenaga listrik. Jakarta: Sekolah Tinggi Teknik - PLN.

[5] ESDM Report. (2020). Design and control of PV hybrid system in practice. Jakarta: Dirjen EBTKE-Kementerian ESDM.

[6] Eurelectric Report. (2015). Hydropower - supporting a power system in transition. Europe: Eurelectric.

[7] Furkan. (2017). Tinjauan perubahan formulasi economic dispatch pada sistem tenaga listrik dalam menyikapi integrasi PLTS skala besar ke dalam jaringan dengan PLTA sebagai pengimbang utama. Jakarta: Sekolah Tinggi Teknik - PLN.

[8] Hidayat, Syarif. (2016). Analisis operasi pembangkit terinterkoneksi untuk mengimbangi fluktuasi daya output sistem PLTS skala besar terhubung jaringan menggunakan simulasi PowerWorld. Jakarta: Sekolah Tinggi Teknik - PLN.

[9] Kita, L.K.W. (2017). Tinjauan perubahan formulasi economic dispatch pada sistem tenaga listrik dalam menyikapi integrasi PLTS skala besar ke dalam jaringan dengan PLTD sebagai pengimbang utama. Jakarta: Sekolah Tinggi Teknik - PLN.

[10] Multi, Abdul. (2013). Tinjauan pembangkit hidrotermis setelah penggabungan PLTA pompa pada sistem tenaga listrik jawa-madura-bali. Jakarta: Institut Sains dan Teknologi Nasional.

[11] Multi, Abdul. (2011). Kajian penjadwalan PLTA pompa dengan metode gradient pada sistem tenaga listrik. Jakarta: Institut Sains dan Teknologi Nasional.

[12] MWH Final Report. (2009). Technical analysis of pumped storage and integration with wind power in the pacific northwest. US: Hydroelectric Design Center.

[13] N. Liang, P. Li, Z. Liu, Q. Song, L. Luo. (2020). Optimal scheduling of island microgrid with seawater-pumped storage station and renewable energi. China: Kunming University of Science and Technology.

[14] Rendroyoko, Ignatius., Sinisuka, Ngapuli., Koesrindartoto, Deddy. (2019). A literature survey of optimization technique of unit commitment implementation in microgrid electricity system with renewable energy sources. Indonesia: Institute Technology of Bandung.

[15] Rendroyoko, Ignatius., Sinisuka, Ngapuli., Koesrindartoto, Deddy. (2019). Optimizing unit commitment schemes for variable RES power plant integration in microgrid systems. Indonesia: Institute Technology of Bandung.

[16] Sarasua, J.I., Lucas, G.M., Platero, C.A., \& Fernandez, J.A.S. (2018). Dual frequency regulation in pumping mode in a wind-hydro isolated system. Spain: Universidad Politecnica de Madrid.

[17] Stan Kaplan. (2008). Power plants: characteristics and costs. US: Congressional Research Service. 
[18] Tuara' Lampung, Alam. (2016). Analisis kemampuan ramping pembangkit untuk mengimbangi fluktuasi output sistem PLTS skala besar terhubung jaringan. Jakarta: Sekolah Tinggi Teknik - PLN.

[19] Windratama, M.R. (2016). Studi pengaturan sistem cadangan putar pembangkit untuk mengantisipasi fluktuasi output sistem PLTS skala besar di UP cirata. Jakarta: Sekolah Tinggi Teknik - PLN.

[20] Wood, Allen J. \& Wollenberg, Bruce F. 1996. "Power Generation, Operation, and Control 2nd Edition", US: John Wiley \& Sons, Inc.

[21] Yi Gu. (2014). Statistical scheduling of economic dispatch and energy reserves of hybrid power systems with high renewable energy penetration. US: National Renewable Energy Laboratory. 